\title{
THE EXISTENCE OF MASLAHAH MURSALAH AS THE BASIS OF ISLAMIC LAW DEVELOPMENT IN INDONESIA
}

\author{
Adi Nur Rohman \\ Fakultas Hukum, Universitas Bhayangkara Jakarta Raya \\ adi.nur@dsn.ubharajaya.ac.id
}

\begin{tabular}{|c|c|c|}
\hline Naskah diterima: & Revisi: & Naskah disetujui: \\
$2 / 09 / 2019$ & $22 / 09 / 2019$ & $4 / 10 / 2019$ \\
\hline
\end{tabular}

\begin{abstract}
Abstrak
Makalah ini bertujuan untuk menganalisis konsepsi maslahah dalam wacana perkembangan hukum Islam. Selanjutnya, makalah ini menguraikan keberadaan masalah dan melihat lebih dalam ke dalam implementasi masalah sebagai dasar untuk pengembangan hukum Islam di Indonesia. Makalah ini adalah yuridis normatif menggunakan pendekatan doktrinal. Pada akhirnya, dapat disimpulkan bahwa konsepsi maslahah adalah metode penggalian hukum Islam yang didasarkan pada aspek manfaat dan kebaikan bagi manusia selama tidak bertentangan dengan norma syariah Islam. Selain itu, implementasi masalah sebagai dasar untuk penemuan hukum Islam di Indonesia tidak dapat disangkal. Hal ini dapat dilihat dari daruratnya undang-undang atau peraturan di bawahnya yang mengatur berbagai aspek hukum Islam di Indonesia dalam menanggapi masalah kehidupan masyarakat sebagai dampak dari zaman dan teknologi.
\end{abstract}

Kata Kunci: eksistensi, maslahah mursalah, hukum Islam.

\begin{abstract}
This paper aims to analyze the conception of maslahah in the discourse of the development of Islamic law. Furthermore, this paper elaborates the existence of maslahah mursalah and looks deeper into the implementation of maslahah as a basis for the development of Islamic law in Indonesia. This paper is normative juridical using a doctrinal approach. In the end, it can be concluded that the conception of maslahah is a method of extracting Islamic law which is based on aspects of benefit and goodness for humans as long as it does not conflict with Islamic sharia norms. In addition, the implementation of maslahah as a basis for the discovery of Islamic law in Indonesia cannot be denied. This can be seen from the emergence of legislation or regulations under it which regulates various aspects of Islamic law in Indonesia in response to the problems of people's lives as the impact of the times and technology.
\end{abstract}

Keywords: existance, maslahah mursalah, Islamic law.

\section{Introduction}

Islam is a religion that is believed to be a universal religion, not limited by time and place. Islamic teachings must be able to be applied in every joint of human life, bearing in 
mind that the Al-Qur'an has stated that the scope of application of Islamic teachings carried by the Prophet Muhammad is for all human beings wherever they are. ${ }^{1}$ Therefore, Islam as a way of life should have a 'place' on this earth without any friction with the culture and style of people's lives. ${ }^{2}$

Islam is a complete system that includes vertical and horizontal relations. These aspects of Islam include: al-ahkam al-i'tiqadiyah, al-ahkam al-'amaliyyah, and al-ahkam alkhuluqiyah. ${ }^{3}$ The Islamic Sharia which regulates God and beliefs correctly is called al-ahkam al-i'tiqadiyyah. Islamic Sharia which regulates the procedures for worship and worship to Allah and associating with fellow human beings in the context of muamalah is called alahkam al-'amaliyyah. The Islamic Sharia which regulates how to behave and behave in a person with God's fellow creatures is called al-ahkam al-akhlaqiyyah.

Subsequently, the term fiqh and Islamic law emerged, in addition to the terms shariah and qanun. Both of these terms appear as a more specific explanation of the various rules contained in al-ahkam al-'amaliyyah, given the fact, many verses of the Qur'an or the hadith of the Prophet SAW relating to this rule, the law is still general or global, even not a few are still vague so that requires further explanation that is more operational. To take legal guidance from the Koran, it requires a correct understanding of the meaning and message contained in the verse. But understanding it is not as easy as understanding the content of the hadith. Therefore, someone who wants to take (istinbath) law from the Qur'an is required to fulfill several requirements and use the right methods and methods.

Islamic law and figh are a set of rules of Allah SWT as a product of ijtihad of mujtahids that are dynamic, moving, and able to follow the development of society in every age and place. That is, where the community moves, when and where the community is located, Islamic law also moves to follow it and be there, setting its rules to be a reference in solving various problems they face. ${ }^{4}$ With this dynamic character, Islamic law is able to respond to various cases in society without being insulated by the conditions of the times and places.

The death of Rasulullah SAW marked the end of the formation of Islamic sharia. However, the development of the times is inevitable so that mujtahids are required to give birth to legal products that are in line with the principles of sharia following the direction of

\footnotetext{
${ }^{1}$ See QS. Saba': 28 dan QS. Al-Anbiya': 107

2 Fathurrahman Djamil, Filsafat Hukum Islam, (Jakarta: Logos Wacana Ilmu, 1997), p. 39.

${ }^{3}$ Suparman Usman, Hukum Islam Asas-Asas dan Pengantar Studi Hukum Islam dalam Tata Hukum Indonesia, Jakarta: Gaya Media Pratama, 2001, p. 23

${ }^{4}$ Dedi Ismatullah, Sejarah Sosial Hukum Islam, Bandung: CV. Pustaka Setia, 2011, cet. ke 1, p. 7
} 
the times and social changes. The belief that the teachings of Islam are able to adapt (adaptable) to people's lives must be able to answer the issues that arise. This certainly will prove that Islamic teachings do not conflict with the progress of science and technology.

One method used by mujtahids in extracting Islamic law from the Qur'an and Hadith is maslahah. Besides the various methods of extracting the law such as qiyas, ijma', istihsan, 'urf, and so on, maslahah is considered acceptable by Islamic jurists although it is still disputed by fiqh scholars. ${ }^{5}$ Compared to other methods, the concept of benefit has been widely used in various regions, given that this method emphasizes aspects directly. ${ }^{6}$ This aspect is in direct contact with the community so that the legal products produced are in line with community expectations.

Maslahah mursalah theory which is often associated with Imam al-Shatibi with the concept of maqasid al-shari'ah is inseparable from other categories of maslahah, such as the maslahah mu'tabarah which is the benefit calculated by Islamic sharia. Maslahah mulghah is the benefit of being rejected on the basis of what has been explained in the text and the problem of mursalah which has not yet been explained in terms of the legal provisions, which are either recommended or rejected. ${ }^{7}$ This latter category then became the basis for developing Islamic law. Indonesia with a majority Muslim population must be able to accommodate the development of applicable Islamic law in accordance with the needs of the community.

The development of social life of the community will continue to develop in the direction of the times. At the same time, Islamic law as one of Indonesia's positive laws must be able to be adaptive in responding to all the demands of the times. This then becomes the basis for the development of Islamic law by referring to authoritative sources without having to get out of the basic norms of Islamic law.

Based on this background, the author will try to examine the conception of the maslahah as a method of extracting Islamic law. In addition, the author will analyze the existence and implementation of problems as a basis for the development of Islamic law in Indonesia so that it will be seen the direction of the development of Islamic law in Indonesia.

\footnotetext{
${ }^{5}$ Mukhtar Yahya dan Fatchurrahman, Dasar-Dasar Pembinaan Hukum Fiqih Islami, (Bandung: al-Ma'arif, 1993), p. 100-118

${ }^{6}$ Fathurrahman Djamil, Op.Cit, p. 141.

${ }^{7}$ Mohammad Daud Ali, Hukum Islam; Pengantar Ilmu Hukum dan Tata Hukum Islam di Indonesia, (Jakarta: PT. RajaGrafindo Persada, 2015), p. 120.
} 


\section{The Conception of Maslahah Mursalah}

Etymologically, the word maslahah is a form of masdar and ism which is derived from the word salaha-yasluhu meaning something that is appropriate, good and useful. ${ }^{8}$ The word maslahah has become Indonesian's absorption into maslahat. The Big Indonesian Dictionary distinguishes between benefits and benefits. Maslahat is something that brings goodness, benefits and uses. Being benefit means having a meaning of usefulness, goodness, benefits, and interests. ${ }^{9}$

Husain Hamid Hasan in his book titled Nazariyah al-Maslahah argues that maslahah when viewed from the side of lafaz is more identical to the meaning of benefits or an occupation which contains or brings benefits. ${ }^{10}$ While al-Buthi in his book Dawabith alMaslahah fi asy-Shari'ah al-Islamiyyah defines maslahah as benefits that can make pleasure or an action that can prevent the results can provide pleasure benefits. The intended pleasure is pleasure that can be felt immediately. Therefore, pleasure is a nature that is always sought after by humans, therefore humans will always try to find this pleasure. ${ }^{11}$

The maslahah according to Wahbah al-Zuhaili is a character that has harmony with sharia determination behavior and its objectives, but there is no specific argument expressing or rejecting it, with projections of realizing benefit and eliminating mafsadah (damage). ${ }^{12}$

Maslahah is generally divided into several categories based on certain categories, including: ${ }^{13}$

1. From the aspect of its strength as a hujjah syar'iyyah there are three kinds:

a) Maslahah Dharuriyah, namely primary interests or basic interests whose existence is needed in human life. Primary interests are the interests that are absolutely needed by humans in their lives. His life has no meaning if there are no primary needs. Human life will be damaged and destroyed if it is not accompanied by the existence of these primary interests. Like al-ahkam alkhamsah which is the primary need of every human being. Therefore, Allah

\footnotetext{
${ }^{8}$ Hendra Hermawan Adinugraha dan Mashudi, “Al-Maslahah Al-Mursalah dalam Penentuan Hukum Islam”, dalam Jurnal Ilmiah Ekonomi Islam, Vol. 4 No. 1, 2018, p. 63-75

${ }_{9}^{9}$ Departemen Pendidikan dan Kebudayaan, Kamus Besar Bahasa Indonesia (Jakarta: BalaiPustaka, 1996), cet. Ke-2, p. 634.

${ }^{10}$ Husain Hamid Hasan, Nazariyyah Al-Maslahah fi Al-Fiqhi Al-Islamiy, (Kairo: Dar al-Nahdah al-'Arabiyyah, 1971), p. 3-4.

${ }^{11}$ Al-Bûtî, Dawâbit al-Maslahah fíasy-Syarî'ah al-Islâmiyyah (Beirut: Muassasah al-Risâlah, 2001), p. 28-29

${ }^{12}$ Wahbah al-Zuhaili, Ushul al-Fiqh al-islami, juz ii (Damaskus: Dar al-Fikri, 1986), p. 799

${ }^{13}$ Amir Syarifuddin, Ushul Fiqih, (Jakarta: Kencana, 2014), p. 348-354
} 
Almighty guarantees the maintenance of the five points by commanding the implementation of all efforts that lead there. Likewise with everything that causes destruction or damage is bad, then God forbids it.

b) Maslahah Hajjiyyah, namely the interests or benefits needed in human life, so that humans do not experience difficulties. The level of human need for it is not at the level of the dharuri so it does not have a serious impact if it does not exist. Such interests if not fulfilled will not damage human life, but will cause difficulties. For example in the field of worship are given relief for plural and qashar prayers and breaking fast for people who are travelers; etc.

c) Mashlahah Tahsiniyah, the benefit of human life needs to him not to the level of dharuri, and also not to the level of Hajj, but these needs need to be met in order to provide perfection and beauty for human life. Such interests if left behind do not complicate human life let alone damage it. For example it is recommended to eat nutritious foods, use vehicles, and so on.

2. From the aspect of harmony and good acceptance by reason with the aim of Islamic sharia in establishing the law, maslahah is divided into three types:

a) Maslahah Mu'tabarah, which is the benefit calculated by Islamic sharia. This means that the intended benefit has direct and indirect foundation and guidance from the shari'ah so that it makes an excuse in the process of establishing law by the mujtahid. Regarding whether direct instructions are given by the Shari'ah, the maslahah is again divided into two categories: (1) Munasib Muatstsir, namely there are direct instructions from the shari'ah that pay attention to the benefit, and (2) Munasib mula im ie there is no direct instructions from the shari'ah either in the form of texts or Ijma 'of the benefit, but indirectly the instructions are there.

b) Maslahah Mulghah is the benefit of being rejected. This benefit is considered good by reason but is not considered by the shari'ah and there are shari'ah instructions that reject it. This means that the mind considers it good and is in line with the aim of the syariah ', but apparently the syara' sets a different law from what is demanded by the benefit. For example syara 'determines that people who have sexual relations during the day of Ramadan are subject 
to punishment by freeing slaves, or fasting two months in a row or feeding 60 poor people. Benefits like this are called mashlahah mulghah. ${ }^{14}$

c) Maslahah Mursalah is a form of benefit that is considered to be good in a reasonable sense, also in line with the objectives of the shari'ah in establishing the law, but there is no directive of shari'ah which establishes and no one rejects it.

From all the above, the scholars mentioned the validity of the instrumentation of the three categories of maslahah. Jumhur ulama agreed to document the mulahabarah maslahah as they also agreed to reject the maslahah mulghah. As for the use of the method of maslahah mursalah in jihad, there is still a dispute in it.

Wahbah al-Zuhaili stated several conditions that must be met in order to be able to use mursalah mashalih, including: $:^{15}$

1. Maslahah must be in accordance with the objectives of sharia, does not conflict with the principles of sharia and does not contradict the texts or propositions that are qath'i.

2. The maslahah must be accepted by reason that it does contain certain benefits, not only in the form of conjectures, let alone weak allegations. This means that the application of these benefits must really produce benefits and avoid danger.

3. The resulting maslahah must be generally accepted for all humans, not only felt by certain individuals or groups. This is because the Shariah law 'applies to all humanity. From this, the application of benefit is not valid that only applies to leaders, families and close people.

\section{Maslahah Mursalah As the Foundation For Legal Excavation}

The conception of maslahah mursalah as part of the legal excavation method certainly cannot be separated from the ijtihad process. Bearing in mind that the revelations have ceased, the role of ijtihad becomes very vital in the future development of Islamic law. Etymologically ijtihad is derived from the word jahada which means "to pour out all abilities" or "carry a burden". ${ }^{16}$ In other meaning, ijtihad means "effort" or "hard effort". Thus ijtihad means "trying hard to achieve or obtain something". Ibrahim Husein identified

\footnotetext{
${ }^{14}$ Abdul Wahhab Khallaf, Ilmu Ushul Fiqh, (Semarang: Dina Utama, 1994), p. 87

${ }^{15}$ Wahbah al-Zuhaili, Op. Cit., p. 799-800.

16 Suparman Usman, Hukum Islam: Asas-Asas dan Pengantar Studi Hukum Islam dalam Tata Hukum Indonesia, Cet. Ke-2, (Jakarta: Gaya Media Pratama, 2002), p. 51.
} 
the meaning of ijtihad with istinbath. The term istinbath comes from the word Nabath which means water which originates from the source that was dug. Therefore according to the language of ijtihad which is "getting something out of hiding". ${ }^{17}$ The term ijtihad means "to devote the ability to obtain sharia law" (Islamic law) on a matter from a detailed legal source (the proposition). ${ }^{18}$

In principle, the istislah method is much used by the friends in giving birth to a legal decision, before the scholars of fiqh and usul formulated it methodologically and systematically. Istislah means establishing the law in matters not mentioned in the text, with consideration for the benefit of humans in general. The principle that applies in the use of istislah is to attract benefits and avoid danger. This concept is well known or at least has been used by generations of friends in the form of practice. ${ }^{19}$ An example of using maslahah mursalah is the justification of collecting income tax for the benefit or benefit of the general public in the context of income distribution or fundraising needed to maintain the public interest, which is not mentioned at all in the Qur'an and As-Sunnah. ${ }^{20}$

According to Mohammad Hashim Kamali, Asmawi was quoted as saying that maslahah was not bound by restrictions as imposed on qiyâs and istihsân; he asked the mujtahid to take the initiative to determine the necessary measures, including the determination of the law of new cases, in order to realize something that was seen as a problem for the public at large. More than that, a general, genuine issue that supports the realization of the objectives of Islamic law, and which does not contradict the texts, is a valid basis, footing and frame of reference for Islamic legal legislation. According to Imran Ahsan Khan Nyazee, the scholars (Islamic jurists) agreed that the maslahah could be applied as the basis for a legal provision, and this maslahah could be used as a rationale when expanding the legal provisions to new cases. This is the basis of the maslahah doctrine. ${ }^{21}$

The concept of maslahah - as the core maqâsid al-syarî‘ ah - is the best alternative for the development of ijtihad methods, where al-Qur'an and Sunnah must be understood through ijtihad methods by emphasizing the maslahah dimension. ${ }^{22}$ The concept of maslahah

\footnotetext{
17 Ibrahim Hosein, Memecahkan Permasalahan Hukum Baru, dalam Haidar Bagir dan Syafiq Basri (Editor), Ijtihad Dalam Sorotan, cet. Ke 4, (Bandung: Mizan, 1996), h. 25.

${ }^{18}$ Abdul Wahhab Khallaf, Ilmu Ushul Fiqh,Cet. Ke-9, (Jakarta: al-Majlis al-A'la al-Indonesiy Li al-Da'wat alIslamiyyat, 1972), h. 22.

${ }^{19}$ Achmad Kholiq, Melacak Sejarah Metodologi Ijtihad, (Bandung: Sahifa, 2009), hlm. 252

20 Ahmad Azhar Basyir, Asas-Asas Hukum Mu'amalat, (Yogyakarta: UII, 1983), hlm. 3.

${ }^{21}$ Asmawi, "Konseptualisasi Teori Maslahah", dalam Jurnal Salam; Jurnal Filsafat dan Budaya Hukum, Vol. 1 No. 2, 2014, p. 311-328.

${ }^{22}$ Asrafi Jaya Bakri, Konsep Maqashid Syari'ah Menurut Al-Syatibi, (Jakarta: RajaGrafindo Persada, 1996), p. 168
} 
is a vehicle for changing the law. This means that through the mechanism of the implementation of this concept the fiqh scholars have a framework for dealing with legal issues, inherent in a legal system based on the texts of the shara '(al-Qur'an and Hadith), which contains a material legal foundation which limited to the affairs of life in a changing environmental situation. ${ }^{23}$ Therefore, the concept of maslahah can provide space and form of legitimacy for the new legal rules that are not explicitly demonstrated by nash syara '.

\section{Maslahah Mursalah as the Basis of Islamic Law Development in Indonesia}

As explained above, that the problem of mursalah becomes an important part in the development of Islamic law, including in Indonesia. Indonesia is a country with a majority Muslim population. As the majority religion, it cannot be denied if many Islamic values are embraced in the life of the nation both in terms of thought, customs (living traditions) and developing behavior. In line with this, the formalization of Islamic law as a national law becomes a legitimate necessity and is recognized in Indonesia through the formalization process or the Islamization of the legislation. Amin Suma defines the Islamization of the legislation as a form of adjusting the laws and regulations to the values and norms of Islamic law. According to him, this formalization process has been going on for a long time and has taken around 30 years. ${ }^{24}$ Some Islamic legal regulations that have been entered in the formalization process to enter into the legislation system in Indonesia such as the formation of marriage laws, zakat, waqf and various laws and other regulations.

The form of the regulations that have been received is actually a form of manifestation of Islamic values in its formal form. That way, Islamic law will enter into a formal legal dimension that is more regulatory and also compels all Indonesian citizens who are Muslim. However, it must be understood that the formalization process must of course be based on authoritative sources, one of which refers to the problem masuraah. Thus, we will all arrive at a point where Islamic law will be more down to earth in Indonesia by looking at aspects of society that are the needs of the Indonesian people at large so that they can be accepted by all Indonesian Muslim communities.

\section{Conclusion}

\footnotetext{
${ }^{23}$ Asmawi, Op. Cit.

${ }^{24}$ M Amin Suma. (2009). Fenomena Perkembangan Islam dan Hukum Islam di Indonesia. Jurnal Hukum Prioris, 2(2), 68-84.
} 
Maslahah is a condition and character that is in harmony with the behavior of the establishment of sharia and its objectives, but there is no specific argument to set or reject it, with the aim of realizing benefit, goodness, and usefulness and also eliminate mafsadah (damage). In general, maslahah is categorized into three parts; dharuriy, haajjiy and tahsiniy.

The concept of maslahah mursalah is the best alternative in terms of developing other ijtihad methods, where the Qur'an and Sunnah must be understood through ijtihad methods by emphasizing the dimension of maslahah. The concept of maslahah is a vehicle for the development and progression of progressive law without the boundary of space and time inherent in the legal system based on the texts of the sharia '(al-Qur'an and Hadith).

In the end, it was seen that maslahah mursalah became an important element in the development of Islamic law in Indonesia. This is due to the formalization of Islamic law in Indonesia which emphasizes many aspects of maslahah in its formal formation so that it can be binding on all citizens who are Muslim. Thus, the existence of the problematic maslahah as a basis for the development of Islamic law finds its locus so as to create an adaptive Islamic law in all walks of life.

\section{Bibliography}

Adinugraha, Hendra Hermawan dan Mashudi, "Al-Maslahah Al-Mursalah dalam Penentuan Hukum Islam”, dalam Jurnal Ilmiah Ekonomi Islam, Vol. 4 No. 1, 2018.

Ali. Mohammad Daud, Hukum Islam: Pengantar Ilmu Hukum dan Tata Hukum Islam di Indonesia, Jakarta: PT. RajaGrafindo Persada, 2015.

Al-Bûtî, Dawâbit al-Maslahah fîasy-Syarî‘ah al-Islâmiyyah, Beirut: Muassasah al-Risâlah, 2001.

al-Zuhaili, Wahbah. Ushul al-Fiqh al-islami, juz II, Damaskus: Dar al-Fikri, 1986.

Asmawi, "Konseptualisasi Teori Maslahah", dalam Jurnal Salam; Jurnal Sosial dan Budaya, Vol. 1 No. 2, 2014.

Bakri, Asrafi Jaya. Konsep Maqashid Syari'ah Menurut Al-Syatibi, Jakarta: RajaGrafindo Persada, 1996.

Basyir, Ahmad Azhar. Asas-Asas Hukum Mu'amalat, Yogyakarta: UII, 1983.

DepartemenPendidikan dan Kebudayaan, Kamus Besar Bahasa Indonesia Jakarta: BalaiPustaka, 1996.

Djamil, Fathurrahman. Filsafat Hukum Islam, Jakarta: Logos Wacana Ilmu, 1997.

Hasan, Husain Hamid. Nazariyyah Al-Maslahah fi Al-Fiqhi Al-Islamiy, Kairo: Dar alNahdah al-'Arabiyyah, 1971.

Hosein, Ibrahim. Memecahkan Permasalahan Hukum Baru, dalam Haidar Bagir dan Syafiq Basri (Editor), Ijtihad Dalam Sorotan, cet. Ke 4, (Bandung: Mizan, 1996. 
Ismatullah, Dedi. Sejarah Sosial Hukum Islam, Bandung: CV. Pustaka Setia, 2011, cet. ke 1.

Khallaf, Abdul Wahhab. Ilmu Ushul Fiqh, Semarang: Dina Utama, 1994.

Khallaf, Abdul Wahhab. Ilmu Ushul Figh,Cet. Ke-9, (Jakarta: al-Majlis al-A'la al-Indonesiy Li al-Da'wat al-Islamiyyat, 1972.

Kholiq, Achmad. Melacak Sejarah Metodologi Ijtihad, Bandung: Sahifa, 2009.

Syarifuddin, Amir. Ushul Fiqih, Jakarta: Kencana, 2014.

Suma, M Amin. 2009. Fenomena Perkembangan Islam dan Hukum Islam di Indonesia. Jurnal Hukum Prioris, Vol. 2 No. 2.

Usman, Suparman. Hukum Islam Asas-Asas dan Pengantar Studi Hukum Islam dalam Tata Hukum Indonesia, Jakarta: Gaya Media Pratama, 2001.

Yahya, Mukhtar dan Fatchurrahman, Dasar-Dasar Pembinaan Hukum Fiqih Islami, Bandung: al-Ma'arif, 1993. 